\title{
"They do not know much, but then, you have to cover the syllabus": The quality imperative - a dilemma for teachers in early grade multilingual classrooms in Kenyan primary schools
}

\author{
Susan Karigu Nyaga \\ SIL Africa | Department of General Linguistics, Stellenbosch University, South Africa \\ E-mail: susan_nyaga@sil.org
}

\begin{abstract}
The centrality of language in any education system cannot be overemphasised. Wolff (2006: 50) sums this up by stating that "language is not everything in education, but without language everything is nothing in education". As such, language mediates knowledge acquisition even when the content of education is not language. The question then arises as to which language is best to use in education. There are no straight answers to this, as education in most countries of the world takes place in multilingual contexts. In Kenya, the language-in-education policy supports the use of the learner's first language as the language of instruction in the first three years of school. The policy, however, remains largely unimplemented for various reasons, among them the multiplicity of first languages that may be represented in one classroom. This article reports on some outcomes of a recently completed doctoral study that investigated teachers' attitudes, skills and strategies in their management of linguistic diversity in multilingual classrooms. Specifically, the article reports on what informs teachers' language choices and prioritisations beyond the policy rhetoric. The study disclosed that the language of examinations and textbooks, the pressure to cover the syllabus, and individual teachers' language repertoires primarily determine which languages are prioritised and how they are used. The findings suggest that quality education for all may remain elusive in multilingual contexts until the language question has been adequately addressed.
\end{abstract}

Keywords: language choices, multilingual classrooms, language of instruction, language-ineducation policy

\section{Introduction}

Sixty years ago, at a meeting sponsored by the United Nations Education, Science and Cultural Organisation (UNESCO), a team of experts deliberating on the issues of language in education unanimously agreed that the best language to use to teach children who are starting school is their mother tongue (MT) ${ }^{1}$. About 40 years later, at the World Education Forum held in Jomtien,

\footnotetext{
1 "Mother tongue" (MT) and "first language" (L1) are used interchangeably in this article.
} 
Thailand in 1990, delegates from 155 countries as well as representatives from 150 governmental and non-governmental organisations all affirmed the perspective that education is a fundamental human right. At this meeting, Education for All (EFA) ideals were articulated in that participating countries were urged to intensify their efforts to address the basic learning needs for all.

The Jomtien EFA targets were only minimally implemented by the year 2000, when another World EFA forum was held in Dakar, Senegal. Here, delegates from over 100 countries adopted the Dakar Framework for Action. The framework reaffirms the commitment to achieving education for all by the year 2015, and UNESCO was tasked with the overall responsibility of co-ordinating the efforts of stakeholders/role players in the work. The Dakar framework further identifies language as a possible barrier to access to schooling. It suggests the use of local languages as a key component in determining the quality and relevance of learning, and therefore, recommends bilingual education for ethnic minorities and respect of their linguistic identities (UNESCO 2000).

In the last decade or so, other education stakeholders and funders have published position papers on the benefits of using the MT in the early years of a child's education (see Save the Children 2007, 2009). UNESCO published another position paper in 2003, entitled "Education in a multilingual world", reiterating their earlier position on the use of learners' MTs in the early years of schooling. The United Nations' Literacy Decade (UNLD 2003-2012) emphasises language issues as part of literacy policy formulation, programme design, capacity-building and research, in the context of enhancing relevance and community participation (Robinson 2004: 44). The Decade of Education for Sustainable Development (DESD 2005-2014) echoes the EFA view of language not only as an important aspect of cultural diversity but also a means of expressing local knowledge and a factor in relevant and effective learning (Robinson 2004).

\section{The study}

In response to the early declarations, many countries moved fast to formulate language-ineducation policies in keeping with their commitments to the attainment of EFA goals. For example, in Kenya, the language-in-education policy supports the use of the learner's first language (L1) as the language of instruction in the first three years of school. Although the policy has been in place for nearly 40 years, it remains largely unimplemented for a number of reasons, among them the multiplicity of L1s that may be represented in one classroom.

This article will refer to data and findings of a recent study, the aim of which was to examine teachers' attitudes, skills and strategies in the management of linguistic diversity amongst yearone learners in multilingual classrooms in four Kenyan primary schools (see Nyaga 2013). The study attended to pertinent aspects of the development of language and literacy skills in the MT as well as other languages of learning. The data for the study were collected through classroom observations, interviews with teachers following the classroom observations, and documentary analysis. The research sites were purposively selected to represent minimal, moderate and high linguistic diversity among the learners as would be anticipated for the rural (schools Y and Z), the peri-urban (school X), and the urban (school W) schools, respectively. All the names of the schools, teachers and learners used in this article are pseudonyms for ethical reasons. The data were analysed following the qualitative content analysis procedures proposed by Henning, Van Rensburg and Smit (2010). 


\section{The basis for teachers' language choices}

One of the objectives of this study was to investigate the strategies that teachers in multilingual classrooms employ to accommodate the linguistic diversity of their learners while keeping educational goals in mind. In the four schools that participated, I noted that teachers often intuitively and unconsciously used a variety of strategies in dealing with linguistic diversity. These included code switching, translating and interpreting, repetition, ritualised participation strategies, verbal and non-verbal scaffolds, and (for some teachers) speaking in the various L1s of the learners. Observations of how the different strategies were employed in actual practice provided important insight into what informed teachers' language choices and how they prioritised these choices in the classrooms. The three primary determining factors as to which strategies would be used when and how were found to be (i) the language of textbooks and examinations, (ii) teachers' own proficiency in the different languages encountered among the learners, and (iii) pressure to cover the prescribed syllabus. These three factors, and how each manifested in the classroom interactions, will be explained and illustrated in the remainder of this article.

\subsection{Language of textbooks and examinations}

English is the language of all the textbooks used in all schools and in every subject, except those used for teaching Kiswahili and those for teaching the MT as a subject (e.g. Kitharaka in school $Z$ ). Thus, teaching and learning materials are not available in the local languages. Also, in virtual defiance of the policy of mother tongue education (MTE) in the first three years, all examinations are set in English - even for standards 1 to 3 where learners aged between 6 and 9 years have often had no prior exposure to English for literacy or learning purposes. The official motivation for this practice is that textbooks and examinations produced in English can be accessed by as many schools in the country as possible. This ensures uniformity in terms of content and standard of work tested at each level of education. Although Kenya's Ministry of Education (MoE) prescribes that examinations should be school-based, this practice of purchasing textbooks and examination papers published centrally continues in total disregard of the de jure directives of the language-in-education policy. Any attempts to change the status quo are met with limiting conditions within the schools, such as a lack of equipment for the printing of their own examination papers.

Tests have been identified as one of the most powerful mechanisms used to manipulate implicit language policies: ideologies that support a dominant language at the expense of educational opportunities for minority language speakers are often imposed and perpetuated in the requirement of language tests or the setting of tests in a language accessible only to the elites (see Shohamy 2004, 2006; Broadfoot 1996). Shohamy, for example, finds that tests have been used to "affect language priorities, language practices and criteria of correctness" (Shohamy 2006: 93), resulting in inclusion of some and exclusion of others. Given the power of test results in determining social order, she argues, those who teach and learn have no option but to comply (Shohamy 2006: 93).

I argue here that compliance with an educational system in a multilingual community that provides teaching and assessment materials in English only, when there is mostly late access to English as a second language (L2), prioritises the language of the tests over other languages regardless of what the declared policy determines on language-in-education. The Kenyan 
teachers who participated in this study all deferred to the power of the tests in their language choices in the classrooms. The following extract illustrates how teachers used English in examination preparation, regardless of the policy of MTE. In the extracts that follow, local language text is italicised while English text and translations are in normal type. Teacher's turns are marked with $\mathrm{T}$ while learner(s)' turns are marked with $\mathrm{L}(\mathrm{s})$.

\section{Extract 1 - School Y (Social Studies lesson)}

(1) T: Twasyokaa twona nyomba ingi twasya isu ni semi-permanent. Twasya ni semi ${ }^{\wedge 2}$ [Then we saw another type of house which we called semi-permanent. We said they are $\mathrm{semi}^{\wedge}$ ]

(2) Ls: Permanent!

(3) T: Semi-permanent. Twona nyomba ingi twasya isu i permanent. Na ingi nasyo twasya $n i$ temporary.

[Semi-permanent. We saw other houses that we called permanent. And others which we said they are temporary]

In this extract, in a grade 1 classroom, teacher $Y$ switches between Kikamba and English. In her code switching, Kikamba is the matrix language ${ }^{3}$ (Myers-Scotton 2006) but key concepts in the topic she is teaching, such as 'semi-permanent', 'permanent' and 'temporary', are given in English, as is evident in turns (1) and (3). This she does because the subject of Social Studies is examined in English, as are all other content subjects in the observed classrooms. Kikamba is the medium of instruction (MoI) in this classroom, the L1 of a majority of the children and of the teacher. Thus, the teacher gives the key terms in English because learners are likely to come across them in the tests. This practice was observed in all study sites regardless of what the predominant MoI was. The following extract gives a further example:

\section{Extract 2 - School Z (Science lesson)}

(4) T: Proteins ni iria itumbithagia gukura - to grow - gukura - to grow [Proteins are those foods which help us to grow - to grow - to grow]

(5) Ls: To grow

(6) T: Carbohydrates - uga carbohydrates

(7) Ls: Carbohydrates

(8) T: Kairi

[Again]

(9) Ls: Carbohydrates

(10) T: Twaciitire carbohydrates. Na i cio itunenkagira inya - energy. Igatunenkera mbi yo? [We called them carbohydrates. And they are the ones that give us energyenergy. They give us what?]

\footnotetext{
${ }^{2}$ The symbol $\wedge$ is used to indicate the rising intonation usually placed at the end of an incomplete word or sentence mainly to evoke a response from learners (by completing the word or sentence) when teachers employ "ritualised participation strategies" in classes.

3 Myers-Scotton's (2006) Matrix Language Framework (MLF) has been used in studies on code switching to determine the matrix language. However, the MLF model was not employed in this study as this was not a study on code switching per se; code switching only emerged as one among the many strategies that this study was seeking to document. As such, the term "matrix language" is used here to refer to the language in which the conversation begins, while the language switched to or inserted into the matrix language is referred to as the "embedded language".
} 
(11) Ls: Energy

(12) T: Inu ingi twaciitire vitamins - twaciitire ata?

[The others we called them vitamins - we called them what?]

(13) Ls: Vitamins

Extract 2 is taken from a science lesson where it is evident that, as in extract 1, teacher $\mathrm{Z}$ code switches between Kiembu (matrix language) and English when teaching. This she does by giving the key concepts in English - 'proteins', 'carbohydrates' and 'vitamins' in turns (4), (6) and (12), respectively - even though Kiembu is the preferred MoI in her context. She goes on to use Kiembu to describe the benefits of the different food nutrients, but key concepts such as 'grow' in turn (4) and 'energy' in turn (10) are given in English.

Both teachers $\mathrm{Y}$ and $\mathrm{Z}$ are aware of their learners' limited proficiency in English. This, rather than just the MTE policy, explains why they do not use the language as MoI. However, because they have to prepare their learners for English examinations, they keep bouncing between English and their preferred MoIs (Kikamba in school Y and Kiembu in school Z), as demonstrated above. This use of the two languages reflects competing desires of the teachers, namely the desire to help the learners understand what is being taught, and the desire to prepare them for examinations that will be written in English.

Following such observations, I concluded that teachers use English as a preparatory precaution for English examinations. Indeed, as Pinnock, Mackenzie, Pearce and Young (2011: 12) warn, when examinations are conducted in national and international languages, it becomes difficult to convince teachers to teach in the local language because if they do, their learners will not be ready for the examinations. Here, the code switching between different languages represents the teachers' awareness of the fact that the learners are not proficient in the language of assessments. Teachers, thus, code switch to ensure that learners not only understand but also know the critical English terms in the content subjects. Sometimes teachers would use two languages that were "foreign" to a majority of the young learners. For example, in the urban school the MT used for teaching is Kiswahili which is an L2 for many learners, and English is also introduced due to assessment taking place in this language, as stated earlier. Teachers had their reasons for their classroom language practices. For instance, the following extract from an interview with teacher Z explains why she used English words even though she would later have to translate them into Kiswahili. Teacher Z's views in this extract are representative of teachers' views in general:

I speak in English because [...] if it is Science, I cannot give the notes in Kiswahili because they will be tested in English. So I have to write the English words. Because like now, the question will come: "We use nose to (dash)". They will have to be tested in English.

Teacher $\mathrm{Z}$ was aware that the learners in her classroom had very low English language proficiency levels since they had only just been introduced to the language, but she still used Kiswahili-English code switching and code mixing. She says that she does this because she has at the forefront of her mind the English examinations her learners are due to write. She even gives an example of the format in which questions are likely to be given in the examinations in English - "We use the nose to have to supply an answer in English. (dash)". For this and many other similar questions, learners 
Shohamy (2001) reports similar observations in her study of a new national reading comprehension test in Israel. She found that the introduction of the test forced teachers to engage in teaching "test-like" materials as reflected in the kinds of texts used and questions they asked in the classroom. When that happens, the alternative of teaching reading in a more integrated manner is not considered. Even at a much higher level, Shohamy found that the introduction of an oral English test in grade 12 resulted in teaching "test-like" content focusing only on tasks included in the tests while ignoring others (Shohamy 2001). In my study, I found that the form and content of what could be expected in tests set by external organisations strongly determined both the teaching and the exercises given to the learners at the end of a lesson. The fact that teachers give lesson notes in English to learners who cannot yet read - not even in their L1 - is indicative of the kind of control that tests have had on teachers' language behaviour and classroom practices.

\subsection{The language proficiency of individual teachers}

My survey of the four schools where data was collected showed that it is no straightforward matter to decide which particular indigenous language should count as the MT to be used in the first three years of schooling. This is because very few schools have learners that represent a single indigenous language community. Even in rural schools, where there is less language diversity than in the urban areas, a certain degree of diversity was clear and was at times accounted for by the appointment of a teacher who does not speak the community language(s). That means that, in all cases, schools have to rely on the fact that the majority of trained teachers are proficient in a number of languages. Thus, although the multilingualism of the community is minimally acknowledged in the languagein-education policy, there is a tacit assumption that teachers are multilingual and can manage teaching multilingual groups of learners.

Some of the teachers who participated in this study indicated that when they noticed learners struggling with the school languages (e.g. with English or Kiswhaili), they would use the learners' L1s wherever possible. For instance, Teacher $\mathrm{W} 1^{4}$ would speak Dholuo, albeit irregularly, to one of the learners in her class who found the school languages, English and Kiswahili, difficult to follow. The teacher explained this practice by saying "nikitaka aelewe ninatumia mother tongue" ('when I want him/her to understand, I use the mother tongue' [Dholuo]). In this particular case, the learner's L1 also happens to be the teacher's L1, so it was quite telling that she felt she had to justify the assistance she was giving. Regular educational considerations would probably welcome and commend such efforts to include a learner who is unfamiliar with the languages of learning.

In a number of instances, this teacher also used words from other languages representing the L1s of learners to overcome a problem often encountered in multilingual communication, namely a "temporary word-finding difficulty, when a word from the other language [is] substituted for a momentarily inaccessible word" (Rose and Van Dulm 2006: 6). For example,

\footnotetext{
${ }^{4}$ At the time of the study, there were two teachers assigned to the same class in school $\mathrm{W}$ and who took turns to teach the class. For the purposes of this study, these teachers were assigned the codes "teacher W1" and "teacher W2" for the class teacher and assistant teacher, respectively. This is a rare scenario considering the high teacherlearners ratio in Kenyan public schools. However, the school had experienced massive transfers of learners and low enrolments following the post-election violence that rocked the country in 2007/2008. The area where the school is located was among the places worst hit by the violence in Nairobi.
} 
in other explanations, she used waruu and minji, which are Kikuyu words for "Irish potatoes" and "garden peas" respectively, and mbuui, which is the Dholuo word for "spider".

In one of the informal discussions with teacher Y, I asked her how she managed to accommodate the different languages represented in her classroom. She explained that since she could speak all three languages represented in her class, she could easily switch from Kikamba (the MoI) to Kitharaka or Kimbeere ${ }^{5}$ whenever there was a need to clarify something to a learner who could not follow the Kikamba explanation. In the classroom observations, teacher Y was found to speak Kitharaka once in a while to Tharaka L1 learners when she felt they had difficulty following in Kikamba.

\subsection{Pressure to cover the syllabus}

My study also revealed that the pressure to cover the syllabus pushed teachers to proceed unabatedly in a single language in the classroom, even if this language was limitedly accessible to many learners. It would, for example, take twice as much time to cover a topic if the teachers were to translate everything said in English into Kiswahili. It would, therefore, appear that the pressure for syllabus coverage prevails, while translation as a strategy falls off the teachers' balancing act, even if only a few learners will be afloat by the time the syllabus has been covered. This is reflected in the words of teacher X when she stated in an interview that "[t]hey do not know much, but then, you have to cover the syllabus".

The following two extracts from lessons in school $\mathrm{W}$ will illustrate this further:

\section{Extract 3 - School W (Mathematics lesson)}

(14) T: We want to do take away. Tunataka kutoa.

(15) T: We will use our fingers. Tutatumia tu vidole zetu.

(16) T: Take away ni kutoa.

(17) $\mathrm{T}$ : Five take away one.

(18) T: Everyone show me your five fingers. Kila mtu anionyeshe vidole tano.

This extract illustrates how everything teacher W2 says in English she repeats in Kiswahili. Since Kiswahili is the preferred MoI in this particular context, teacher W2 could be using English for two reasons. Firstly, because all the materials for teaching content subjects are in English, teacher W2 could be finding it easier to follow the materials directly and then translate them into Kiswahili. Secondly, it is also possible that teacher W2 is using English as a preparatory mechanism for English examinations (cf. section 3.1). Teacher W2 is keenly aware that her learners are not proficient in the language of the textbooks and examinations. Hence, she translates everything she says in English into Kiswahili to enhance learners' understanding of the content, even though not all of the learners are proficient in Kiswahili. However, in a different lesson by teacher W1 in the same classroom, she proceeds with the lesson in English as if completely oblivious to the language challenge amongst her learners. The following extract illustrates this:

\footnotetext{
${ }^{5}$ Kitharaka, Kimbeere and Kikamba belong to the same language family and therefore are, to some degree, mutually intelligible.
} 


\section{Extract 4 - School W (Social Studies lesson)}

(19) T: Now last time you discussed with teacher [W2] the types of houses. Types of ${ }^{\wedge}$

(20) Ls: Houses

(21) T: Types of what?

(22) Ls: Houses

(23) T: Yes, the types of houses we have in our communities. We are still looking at the types of houses. You talked about two types of houses. Remind me the types of houses you talked about. Do not look at the walls because there were labels on the walls with the types of houses. Tell me one of the houses you talked about.

(24) Ls: Sticks.

As can be seen from this extract, teacher W1 proceeds with this Social Studies lesson in English. She is aware that there are learners in this class who do not speak English or Kiswahili but she just carries on with the lesson in English, ignoring the language reality in her classroom. This could be interpreted to mean that sometimes teachers may feel overwhelmed by having to deal with linguistically diverse learners. When they feel overwhelmed, they may not employ any inclusive strategies, even when they know that their learners do not understand what they are saying.

This interpretation is in line with the words of teacher W1 when she says that "nikitaka aelewe ninatumia mother tongue" ("when I want him/her to understand, I use the mother tongue'), as discussed in section 3.2. This could be interpreted to mean that even when teachers are aware that learners do not understand what they are talking about and want to help them, these teachers may sometimes become overwhelmed by the challenge and just carry on with lessons as if the language barrier was non-existent. The fact that this teacher used Dholuo translations and code switching to explain content to an individual Dholuo-L1 child to enhance understanding, means that this teacher was aware of some of the ways in which she could make her classroom more inclusive but chose not to use them in certain instances.

A similar situation was observed in school $\mathrm{Y}$ where, although the teacher had reported in an interview that she spoke Kitharaka and Kimbeere to Tharaka and Mbeere children respectively to enhance their understanding, no instances of speaking Kimbeere to Kimbeere-L1 children were observed throughout the time of my visit to her classroom. Instead, the teacher taught in Kikamba and switched between all other languages - Kitharaka, Kiswahili and English - but not Kimbeere. What this may mean is that Kimbeere-L1 children are less included in classroom interactions and may not understand most of what is said in Kikamba. This was happening despite the fact that the teacher was aware that not all her learners could understand Kikamba well, as reflected in her response to the question regarding her learners' proficiency in Kikamba. Her response was that they understand Kikamba, "hii lugha ya kuongea" ('the spoken form of language') - referring to the Basic Interpersonal Communicative Skills (BICS) theorised by Cummins (1980). It is possible that having to switch between all the languages represented in a classroom may overwhelm the teacher, even when he/she has good intentions of being linguistically inclusive to her learners, and may result in one or more languages being completely forgotten in the process.

Following these findings, suggestions are made in the next section for improving language choices and practices in multilingual learning contexts. I have termed these the "new imperatives for education, training and learning" in light of the post-2015 EFA agenda. 


\section{New imperatives for education, training and learning}

The negative effects of ill-prepared teachers on language-in-education policy implementation have been documented in a number of studies (see Plüddeman, Mati and Mahlalela-Thusi 2000; Zappa-Hollman 2007). Although all of the teachers in the current study were graduates from accredited teacher training colleges (TTCs) in Kenya, they all reported that they had not received any training in particular on how to deal with linguistically diverse learners. It has also been documented elsewhere that the TTC curriculum does not directly address the teaching of MTs as it is assumed that anyone who can speak a language can also use it for instruction or teach learners to read it (see Bamgbose 1991, Musau 2003).

Byrnes, Kiger and Manning (1997: 642) assert that "the most obvious avenue for more effectively preparing teachers to work with language minority students is through formal training". According to these authors, formal training in teaching linguistically diverse learners should include "carefully planned presentations and field experiences that focus on attitudes necessary to understand and appreciate language development and cultural diversity" (Byrnes et al. 1997: 642). The findings of this study point to the need for restructuring the teacher education curriculum to include aspects of language awareness such as psycholinguistics, sociolinguistics, language planning, and language and education. This would give teachers a broader basis from which to make language choices in their classrooms.

Powell (1996: 60) suggests that "as students in classrooms continue to become increasingly diverse, $[\ldots]$ new instructional demands have come to the forefront of classroom teaching". This calls for teachers to be ever vigilant in their attempts to be inclusive of learners who come from diverse as opposed to bounded systems. Commensurate with teachers' vigilance is the need for teacher education programmes to incorporate this changing nature of the classroom by adapting their programmes so that teachers are equipped with the requisite skills for dealing with multilingual learning environments, which are now the norm rather than the exception everywhere. This is imperative in the thinking and deliberations on quality education, training and learning.

\section{Conclusion}

This article provides a glimpse into the implementation of the Kenyan language-in-education policy in multilingual classrooms. I find that although the language-in-education policy supports the use of MTs, no resources are allocated towards producing textbooks and other school materials in the languages advocated for by the policy. Instead, materials are published exclusively in English (except those for teaching Kiswahili as a language subject) despite the fact that the recommended MoI for urban schools is Kiswahili and a variety of indigenous languages in the rural areas. English is preferred as the MoI over all other languages as reflected in the textbooks and examinations which are printed and written, respectively, in English. Similarly, initial teacher preparation does not prepare the teachers for multilingual teaching environments. Thus, government policy may have good intentions in terms of support of early learning through the medium of the MT, but policy implementation is undermined by limited supportive actions beyond the policy rhetoric.

Commenting on Tanzanian learners' expressed desire to be instructed in English even though they understood Kiswahili better, Roy-Campbell (1992) views this as indicative of the 
perception of where power is located in society (cf. Nyaga 2013, Ssentanda, 2013). Yates (1995) views the anomaly of preference of little understood languages as MoI over familiar languages as indicative that language preference is not simply a matter of pedagogical effectiveness but is also linked to the wider political and socio-political factors, amongst them the perceived status of different languages. In the Kenyan classrooms studied, the power of English over other languages is evident in teachers' classroom practices, the examinations and the textbooks used. The perceived economic utility of English in the broader socio-political context mirrors in the classrooms through what I call here the "perceived examination utility" of English. The perceived examination utility of English in the observed classrooms is reflected in the language choices and prioritisations teachers make in these classrooms. In this regard, Alexander (2005) suggests that research should be undertaken that will demonstrate the economic rationality of Mother Tongue-Based Multilingual Education (MTBMLE) beyond pedagogical and psycholinguistic advantages, with an ultimate goal of showing the business and government sectors as well as society in general that local languages have market value.

King (2004: 39) observes that in plurilingual societies, multilingualism is viewed more as a way of life than a problem to be solved. She finds that in such societies, people have somehow "developed an ethos which balances and respects the use of different languages in the daily life" of the community (King 2004: 39). According to her, the challenge is for education systems to adapt these complex realities of language use in these societies in order to provide quality education where there is a balance between the learners' needs and the social, political and cultural demands of the society. In my view, a critical question here would therefore be: what is in the community that enables community members to manage their multilingualism so well, and which schools could borrow to facilitate positively tapping into linguistic diversity as a resource as opposed to seeing it as a problem? In the answer to this question lies the solution to managing linguistic diversity in multilingual learning environments. In the African context, such a solution would seek to capitalise on the fact that many people grow up as multilinguals (see, for example, Banda 2009, 2010; Glanz 2013; Heugh, Benson, Bogale and Yohannes 2007) and that they function very well linguistically in society. I argue here that with proper placement and allocation of teachers, this societal multilingualism could be harnessed to promote meaningful learning and, consequently, education quality would be greatly improved. Once teachers are placed in the classrooms, attention to all ends in the continua of biliteracy (Hornberger 2003) would yield desirable results.

The interrogation of and engagement with a community's multilingual practices are necessary in the creation of an enabling environment for academic development, which should be a deliberate aim of any education system in any multilingual context. Only in such an environment can linguistic diversity be exploited and/or harnessed to assure academic development and advancement of all learners, regardless of their linguistic backgrounds, in both the specific context of this research and other similar contexts.

\section{Acknowledgements}

I would like to thank SIL Africa, particularly the Advocacy and Alliance Building (AAB) department, for providing the funds (through the PRISMA mentorship programme) to attend the conference where the paper, on which this article is based, was first presented. My thanks 
also go to Prof. Christine Anthonissen from the Department of General Linguistics at Stellenbosch University for supervising the doctoral thesis from which this article stemmed.

\section{References}

Alexander, N. 2005. Mother tongue based bilingual education as political and educational strategy. Available online: http://www.acalan.org/fr/confeven/rencontre consultative/article neville.pdf (Accessed 10 August 2015).

Bamgbose, A. 1991. Language and the nation: The language question in sub-Saharan Africa. Edinburgh: Edinburgh University Press.

Banda, F. 2009. Critical perspectives on language planning and policy in Africa: Accounting for the notion of multilingualism. Stellenbosch Papers in Linguistics PLUS 38: 1-11.

Banda, F. 2010. Defying monolingual education: Alternative bilingual discourse practices in selected coloured schools in Cape Town. Journal of Multilingual and Multicultural Development 31(3): 221-235.

Broadfoot, P. 1996. Education, assessment and society: A sociological analysis. Buckingham: Open University Press.

Byrnes, D.A., G. Kiger and M.L. Manning. 1997. Teachers' attitudes about language diversity. Teaching and Teacher Education 13(6): 637-644.

Cummins, J. 1980. The cross-lingual dimensions of language proficiency: Implications for bilingual education and optimal age issue. TESOL Quarterly 14(2): 175-187.

Glanz, C. 2013. Why and how to invest in African languages, multilingual and multicultural education in Africa. In H. McIlwraith (Ed.) Multilingual education in Africa: Lessons from the Juba Language-in-Education Conference. London: British Council. pp. 57-67.

Henning, E., W. Van Rensburg and B. Smit. 2010. Finding your way in qualitative research. Pretoria: Van Schaik Publishers.

Heugh, K., C. Benson, B. Bogale and M.A.G. Yohannes. 2007. Final report study on medium of instruction in primary schools in Ethiopia. Available online: http://mlenetwork.org/sites/default/files/Final report study on Medium of Instruction in primary schools in Ethiopia - Heugh et al 2007.pdf (Accessed 12 March 2013).

Hornberger, N.H. 2003. Continua of biliteracy. In N.H. Hornberger (Ed.) Continua of biliteracy: An ecological framework for educational policy, research, and practice in multilingual settings. Clevedon: Multilingual Matters. pp. 3-34.

King, L. 2004. Education in a multilingual world: UNESCO's position. Available online: http://www.norrag.org/en/publications/norrag-news/online-version/language-politics-and-thepolitics-of-language-in-education/detail/education-in-a-multicultural-world-unescosposition.html (Accessed 6 July 2012). 
Musau, P. 2003. Linguistics human rights in Africa: Challenges and prospects for indigenous languages in Kenya. Language, Culture and Curriculum 16(2): 155-164.

Myers-Scotton, C. 2006. Multiple voices: An introduction to bilingualism. Oxford: Blackwell Publishing Ltd.

Nyaga, S.K. 2013. Managing Linguistic Diversity in Literacy and Language Development: An Analysis of Teachers' Skills, Attitudes and Strategies in Multilingual Classrooms in Kenyan Primary Schools. Unpublished PhD thesis, Stellenbosch University.

Pinnock, H., P. Mackenzie, E. Pearce and C. Young. 2011. Closer to home: How to help schools in low-and middle-income countries respond to children's language needs. London: Save the Children, UK.

Plüddemann, P., X. Mati and B. Mahlalela-Thusi. 2000. Problems and possibilities in multilingual classrooms in the Western Cape. Available online: http://www.praesa.org.za/ files/2012/07/Paper2.pdf (Accessed 30 October 2015).

Powell, R. 1996. "The music is why I teach": Intuitive strategies of successful teachers in culturally diverse learning environments. Teaching and Teacher Education 12(1): 49-61.

Robinson, C. 2004. Language, EFA and the MDGs: What's the connection? Available online: http://www.norrag.org/issues/34/en/language-politics-and-the-politics-of-language-\%28ineducation\%29.html (Accessed 6 July 2012).

Rose, S. and O. van Dulm. 2006. Functions of code switching in multilingual classrooms. Per Linguam 22(2): 1-13.

Roy-Campbell, Z.M. 1992. Power or Pedagogy: Choosing the Medium of Instruction in Tanzania. Unpublished PhD thesis, University of Wisconsin-Madison.

Save the Children. 2007. The use of languages in children's education: A policy statement. London: Save the Children, UK.

Save the Children. 2009. Steps towards learning: A guide to overcoming language barriers in children's education. London: Save the Children, UK.

Shohamy, E. 2001. The power of tests: A critical perspective of the use of language tests. Singapore: Longman.

Shohamy, E. 2004. Assessment in multicultural societies: Applying the principles and practices to language testing. In B. Norton and K. Toohey (Eds.) Critical pedagogies and language learning. London: Cambridge University Press. pp. 72-93.

Shohamy, E. 2006. Language policy: Hidden agenda and new approaches. London: Routledge.

Ssentanda, M.E. 2013. Exploring connections: Reflections on mother-tongue education in postcolonial Uganda. Stellenbosch Papers in Linguistics PLUS 42: 281-296. 
UNESCO. 2000. World Education Forum: Dakar framework for action. Paris: UNESCO.

UNESCO. 2003. Education in a multilingual world. Paris: EBSCO Publishing.

Wolff, H.E. 2006. Background and history - Language politics and planning in Africa. In H. Alidou, A. Boly, B. Brock-Utne, Y. Satina Diallo, K. Heugh and H.E. Wolff (Eds.) Optimizing learning and education in Africa - the language factor: A stock-taking research on mother tongue and bilingual education in sub-Saharan Africa. Available online: http://www.adeanet.org/adeaPortal/adea/downloadcenter/Ouga/B3 1 MTBLE en.pdf (Accessed 10 May 2012).

Yates, R. 1995. Functional literacy and the language question. International Journal of Educational Development 15(4): 437-447.

Zappa-Hollman, S. 2007. EFL in Argentina's schools: Teachers' perspectives on policy changes and instruction. TESOL Quarterly 41(3): 618-625. 